\title{
Study on Financing Risks Evaluation System of Private Lending to SMEs Basing on FAHP
}

\author{
Qingguo Zhao, Jing Zhang, Lirui Zhao \\ Department of Economics and Management, Shenyang University of Aeronautics and Astronautics, Shenyang, Liaoning \\ Province, China \\ Zhqg1000@163.com,13315961095@163.com, zhaolr1988@163.com
}

\begin{abstract}
Small and medium enterprises, as an increasingly important role in China's national economy, have difficulties in obtaining finance from formal financial support. So private lending becomes the main choice of the majority of SME financing at this stage,but financing risk should not be ignored. This article is to guard how to be against and control private lending financing risk from the small business itself. It first selects the relevant indicators to establish risk assessment index system and then uses fuzzy analytic hierarchy process (ahp) to determine the index weight and finally evaluates risk level. All in all this paper is trying to provide a method of reference to help the small and medium enterprises to acquire timely identification, accurate evaluation and effective control of financing risk.
\end{abstract}

Index Terms - small and medium-sized enterprise, private lending financing, risk evaluation, fuzzy analytic hierarchy process

\section{Introduction}

Private lending refers to borrowing and lending money between citizens, citizens and legal persons, as well as citizens and other organizations.[1] The private lending financing of small and medium-sized enterprise is a direct financing behavior of giving and receiving credit using money(may also include a small amount of material) as the subject matter, often conducted between small and medium-sized enterprises (or small and medium-sized business owners) and natural person , and all kinds of standard will guild in certain geographic range. Small and medium-sized enterprise private lending has a long history[2]. However, as in Wenzhou, Zhejiang province and Ordos in Inner Mongolia where the boss "run road" phenomenon is frequent, private lending financing risk is thoroughly exposed. This will undoubtedly sound the alarm to SME involved in private lending financing. Therefore, studying the private lending financing risk assessment to help SMEs identify, prevent and control financial risks timely and effectively, is far-reaching and urgent.

\section{The Design of SME Private Lending Financing Risk Index System}

Scientific and effective SME private lending financing index system is a prerequisite of risk assessment, and the selection of indicators determines the risk assessment results[3]. Following the principle of systematic, scientific, pertinence and operability, the construction of a private lending financing risk evaluation index system applicable to small and medium-sized enterprise is as follows:

\section{Implementation of SMEs Private Lending Financing Risk Assessment Method}

SMEs private lending financing risk evaluation is about complex muti-objective decision making [4]. In this paper, combining the fuzzy analytic hierarchy process (ahp) and fuzzy comprehensive evaluation method, the index weight is calculated by the fuzzy analytic hierarchy process (ahp), and then evaluate the risk using the comprehensive evaluation method in the fuzzy mathematics comprehensive evaluation. Specific implementation steps are as follows:

Step1: construct a hierarchical model, shown in TABLE I.

TABLE I SME Private Lending Financing Risk Index System

\begin{tabular}{|c|c|c|}
\hline Numerical order & Level indicator & Secondary indicators \\
\hline 1 & \multirow{5}{*}{ Credit risk A } & Working capital $\mathrm{A}_{1}$ \\
\hline 2 & & liquidity ratio $\mathrm{A}_{2}$ \\
\hline 3 & & Risk factor $\mathrm{A}_{3}$ \\
\hline 4 & & Cash flow debt ratio $\mathrm{A}_{4}$ \\
\hline 5 & & Enterprise credit value degree $\mathrm{A}_{5}$ \\
\hline 6 & \multirow{4}{*}{ Decision risk B } & Entrepreneur's education $\mathrm{B}_{1}$ \\
\hline 7 & & Professional standards $\mathrm{B}_{2}$ \\
\hline 8 & & Management experience $\mathrm{B}_{3}$ \\
\hline 9 & & Risk attitude $\mathrm{B}_{4}$ \\
\hline 10 & \multirow{4}{*}{ Operational risk $\mathrm{C}$} & Contract risk $\mathrm{C}_{1}$ \\
\hline 11 & & Interest rate risk $\mathrm{C}_{2}$ \\
\hline 12 & & Term risk $\mathrm{C}_{3}$ \\
\hline 13 & & Guarantee risk $\mathrm{C}_{4}$ \\
\hline 14 & \multirow{3}{*}{ Legal risk D } & High interest rate risk $\mathrm{D}_{1}$ \\
\hline 15 & & Main risk $\mathrm{D}_{2}$ \\
\hline 16 & & Use risk $D_{3}$ \\
\hline
\end{tabular}

Note: Risk factor $\mathrm{A}_{3}=$ Current liabilities / Amount of private lending. It said the proportion of private lending in current liabilities. The higher the percentage, the greater the risk.

Step2:draw the membership of every two factors through comparison, structure fuzzy consistent matrix,according to literature[5] (values see TABLE $\amalg$ ). 
TABLE II $\quad 0.1 \sim 0.9$ Number of Scaling

\begin{tabular}{|l|l|l|}
\hline Scale & Definition & Explanation \\
\hline 0.5 & $\begin{array}{l}\text { Equally } \\
\text { important }\end{array}$ & $\begin{array}{l}\text { Comparing the two elements, they are equally } \\
\text { important }\end{array}$ \\
\hline 0.6 & $\begin{array}{l}\text { Somewhat } \\
\text { important }\end{array}$ & $\begin{array}{l}\text { Comparing two elements, an element is slightly } \\
\text { more important than the other one }\end{array}$ \\
\hline 0.7 & $\begin{array}{l}\text { Obviously } \\
\text { important }\end{array}$ & $\begin{array}{l}\text { Comparing two elements, an element is obviously } \\
\text { more important than the other one }\end{array}$ \\
\hline 0.8 & $\begin{array}{l}\text { Much more } \\
\text { important }\end{array}$ & $\begin{array}{l}\text { Comparing two elements, an element is much } \\
\text { more important than the other one }\end{array}$ \\
\hline 0.9 & Essential & $\begin{array}{l}\text { Comparing two elements, an element is extremely } \\
\text { more important than the other one }\end{array}$ \\
\hline $0.3,0.2$, & $\begin{array}{l}\text { Anti } \\
\text { comparison }\end{array}$ & $\begin{array}{l}\text { If we can obtain judgment } \mathrm{r}_{\mathrm{ij}} \text { by comparing } \\
\text { element } \mathrm{C}_{\mathrm{i}} \text { with element } \mathrm{C}_{\mathrm{j}}, \text { then we get the judge } \\
\text { ment } \mathrm{r}_{\mathrm{ji}}=1-\mathrm{r}_{\mathrm{ij}}\end{array}$ \\
\hline
\end{tabular}

Step3: single-level sorting-according to the nature of fuzzy consistent matrix, find the weight of each index layer $\mathrm{W}_{\mathrm{i}}$. According to the three kinds of methods to seek power values given by Jijun Zhang in the literature [6], select the third kind of sorting formula to evaluation $\mathrm{W}_{\mathrm{i}}$, as follows:

$$
\begin{gathered}
W_{i}=\frac{1}{n}-\frac{1}{2 a}+\frac{1}{n a} \sum_{k-1}^{n} r_{i k} \\
\mathrm{i}=1,2,3 \cdots \mathrm{n}
\end{gathered}
$$

Formula: where $n$ is the order of $r, a=(n-1) / 2$

Such as the principles of target layer of fuzzy consistent matrix and weight as shown in TABLE III :

TABLE III The Fuzzy Consistent Matrix and Weights of Indicators for Each Standard Layer Corresponding to The Target Layers

\begin{tabular}{|c|c|c|c|c|c|}
\hline Risk & A & B & C & D & $\mathrm{W}_{\mathrm{i}}$ \\
\hline A & 0.500 & 0.650 & 0.400 & 0.250 & 0.217 \\
\hline B & 0.350 & 0.500 & 0.250 & 0.100 & 0.117 \\
\hline C & 0.600 & 0.750 & 0.500 & 0.350 & 0.283 \\
\hline D & 0.750 & 0.900 & 0.650 & 0.500 & 0.383 \\
\hline
\end{tabular}

Similarly, we can obtain the corresponding weights results from fuzzy consistent matrix of the criterion level A,B,C,D.

$$
\begin{aligned}
& \mathrm{W}_{1}=[0.110,0.135,0.235,0.310,0.210] \\
& \mathrm{W}_{2}=[0.142,0.308,0.408,0.142] \\
& \mathrm{W}_{3}=[0.333,0.367,0.200,0.100], \mathrm{W}_{4}=[0.400,0.250,0.350]
\end{aligned}
$$

Step4: use the fuzzy comprehensive evaluation method for comprehensive evaluation.

\section{Risk Evaluation Method for Private Lending Financing for SMEs}

Evaluation of private lending for SMEs is a multivariate evaluation of financing risk assessment work, and has a fuzzy. So generally it uses the method of fuzzy mathematics to evaluation. First of all, it is based on the real-life evaluation standards: high risk, risk in general, low risk, membership assignment using fuzzy mathematics methods, establish evaluation set $V=\left\{\mathrm{v}_{1}, \mathrm{v}_{2}, \mathrm{v}_{3}\right\}$ corresponding,specific evaluation criteria in the attached list: TABLE V.

\section{A. Determine the evaluation matrix}

First set up the sample table to carry out the investigation and study, comprehensive calculation of sample collection, structure evaluation matrix R.Element $r_{i j}$ of $R$ is: make index $i$ of a layer to the first $\mathrm{v}_{\mathrm{j}}(\mathrm{j}=1,2,3)$ evaluation of evaluation members accounts for the proportion of the sample. For example, an indicator $\mathrm{A}$ of the small and medium enterprises (credit risk) level survey comprehensive results are described in the following table $R_{1}$. One for index $A_{1}$ (working capital), $r_{11}$ people think risk is high, people with $r_{12}$ think risk is general, $r_{13}$ people think risk is low, $r_{11}+r_{12}+r_{13}=1$.In accordance with this approach to get SMEs $\mathrm{B}$ indicator (decision risks) evaluation matrix $\mathrm{R}_{2}, \mathrm{C}$ indicators (operational risk) assessment matrix $\mathrm{R}_{3}, \mathrm{D}$ index (legal risk) assessment matrix $\mathrm{R}_{4}$.

\section{B. Primary index fuzzy evaluation}

According to a certain layer fuzzy evaluation matrix and its corresponding index weight vector $\mathrm{W}_{\mathrm{i}}$, calculate the level of level fuzzy evaluation:

$$
\begin{gathered}
E_{i}=W_{i} \bullet R_{i} \\
\mathrm{i}=1,2,3,4
\end{gathered}
$$

Type: "•" for the fuzzy synthesis operation symbols

Such as:

A Matrix of Evaluation Index

\begin{tabular}{|l|l|l|l|}
\hline $\mathrm{R}_{1}$ & $\mathrm{~V}_{1}$ & $\mathrm{~V}_{2}$ & $\mathrm{~V}_{3}$ \\
\hline $\mathrm{A}_{1}$ & $\mathrm{r}_{11}$ & $\mathrm{r}_{12}$ & $\mathrm{r}_{13}$ \\
\hline $\mathrm{A}_{2}$ & $\mathrm{r}_{21}$ & $\mathrm{r}_{22}$ & $\mathrm{r}_{23}$ \\
\hline $\mathrm{A}_{3}$ & $\mathrm{r}_{31}$ & $\mathrm{r}_{32}$ & $\mathrm{r}_{33}$ \\
\hline $\mathrm{A}_{4}$ & $\mathrm{r}_{41}$ & $\mathrm{r}_{42}$ & $\mathrm{r}_{43}$ \\
\hline $\mathrm{A}_{5}$ & $\mathrm{r}_{51}$ & $\mathrm{r}_{52}$ & $\mathrm{r}_{53}$ \\
\hline
\end{tabular}

Note: $\sum_{j=1}^{3} r_{i j}=1, \mathrm{i}=1,2, \ldots \mathrm{n}$

According to the type (2)

$$
\mathrm{E}=\{0.110,0.135,0.235,0.310,0.210\} \bullet
$$

$$
\left\{\begin{array}{lll}
r_{11} & r_{12} & r_{13} \\
r_{21} & r_{22} & r_{23} \\
r_{31} & r_{32} & r_{33} \\
r_{41} & r_{42} & r_{43} \\
r_{51} & r_{52} & r_{53}
\end{array}\right\}=\left\{e_{11}, e_{12}, e_{13}\right\}
$$

That is for index $\mathrm{A},{ }^{e_{11}}$ people think too little working capital, and financing risk is big; ${ }^{e_{12}}$ people think a lot of working capital, and the financing risk in general; ${ }^{e_{13}}$ others think that working capital abundant, financing risk is small, comprehensive evaluation for $\operatorname{Max}\left\{e_{11}, e_{12}, e_{13}\right\}$ corresponding 
level of risk. By the same token, the risk index $\mathrm{B}$ evaluation results $\mathrm{E}_{2}=\left\{e_{21}, e_{22}, e_{23}\right\}$; the risk index $\mathrm{C}$ evaluation results $\mathrm{E}_{3}=\left\{e_{31}, e_{32}, e_{33}\right\}$; the risk index $\mathrm{D}$ evaluation results $\mathrm{E}_{4}=\left\{e_{41}, e_{42}, e_{43}\right\}$,comprehensive evaluation for $\operatorname{Max}\left\{e_{\mathrm{i} 1}, e_{\mathrm{i} 2}, e_{\mathrm{i} 3}\right\}$ level of risk.

\section{The secondary fuzzy comprehensive evaluation}

Primary index fuzzy evaluation only reflect the individual risk evaluation of small and medium-sized enterprises selecting the private lending financing, and does not reflect the total size of the financing risk. Obtained in the evaluation section of the primary index fuzzy evaluation matrix $E_{1}, E_{2}$, $\mathrm{E}_{3}, \mathrm{E}_{4}, \mathrm{Using}$ primary index fuzzy evaluation matrix to establish secondary evaluation matrix, according to the type of target layer (2) obtained fuzzy comprehensive evaluation are shown in TABLE IV.

TABLE IV Target Layer Fuzzy Comprehensive Evaluation

\begin{tabular}{|c|c|c|c|c|c|}
\hline $\begin{array}{l}\mathrm{A}, \mathrm{B}, \mathrm{C}, \mathrm{D} \\
\text { indicators } \\
\text { weight } \mathrm{W}_{\mathrm{i}}\end{array}$ & $\begin{array}{c}\text { A, } \\
\text { seco }\end{array}$ & $\begin{array}{l}\text { D } \\
\text { ury e } \\
\text { atrix }\end{array}$ & $\begin{array}{l}\mathrm{x} \text { of } \\
\text { tion } \\
\end{array}$ & $\begin{array}{l}\text { The evaluation } \\
\text { results } \mathrm{E}=\mathrm{W}_{\mathrm{i}} \bullet \mathrm{R}\end{array}$ & $\begin{array}{c}\text { Comprehensive } \\
\text { evaluation }\end{array}$ \\
\hline 0.217 & $\mathrm{e}_{11}$ & $\mathrm{e}_{12}$ & $e_{13}$ & \multirow{4}{*}{$e_{1}, e_{2}, e_{3}$} & \multirow{4}{*}{$\begin{array}{c}\operatorname{Max}\left\{e_{1}, e_{2}, e_{3}\right\} \\
\text { corresponding } \\
\text { risk grade } \mathrm{v}_{\mathrm{j}}\end{array}$} \\
\hline 0.117 & $e_{21}$ & $\mathrm{e}_{22}$ & $\mathrm{e}_{23}$ & & \\
\hline 0.283 & $\mathrm{e}_{31}$ & $\mathrm{e}_{32}$ & $\mathrm{e}_{33}$ & & \\
\hline 0.383 & $\mathrm{e}_{41}$ & $\mathrm{e}_{42}$ & $\mathrm{e}_{43}$ & & \\
\hline
\end{tabular}

\section{Conclusions}

Currently using fuzzy analytic hierarchy process (ahp) to evaluate the small and medium-sized enterprise private lending financing risk, not only overcome the deficiency of the ahp consistency test but it is more scientific and operational. Small and medium-sized enterprises can choose private lending financing clearly and realize where the risks are and whether the risk is big or small, which helps to targeted risk prevention and control work more purposively, so as to improve the enterprise's financing ability and financing level.

\section{References}

[1] Danyang Luo, Private financing of small and medium-sized enterprises, Beijing: China financial press, 2009.

[2] Chaoju $\mathrm{Hu}$, Small and medium-sized enterprise private lending activity to rational analysis. Journal of Financial and Economic, 6, pp.33-34, 2010.

[3] Nianchun Xiong, Small and medium-sized enterprise private lending risk control thinking.Journal of Accounting communication, 11, pp.152-153, 2011.

[4] Yulin Lan, Small and medium-sized enterprise private lending risk prevention research. Journal of Business information, 3, pp.23-24, 2012.

[5] Yuhui Tao, How to build the fuzzy consistent judgement matrix in fuzzy analytic hierarchy process (ahp).Journal of Sichuan normal university.3, pp.282-285, 2002.

[6] Jijun Zhang, Fuzzy consistent judgment matrix, a comparative study of three kinds of sorting methods. Journal of Systems engineering and electronics, 25(11), pp.1370-1372, 2003.

\section{Attached List}

TABLE V Risk Level Evaluation

\begin{tabular}{|c|c|c|c|c|}
\hline Level indicator & Secondary indicators & High risk & Risk in general & Low risk \\
\hline \multirow{5}{*}{$\begin{array}{l}\text { Credit risk } \\
\text { indicators A }\end{array}$} & Working capital $\mathrm{A}_{1}$ & $\begin{array}{l}\text { Less than or equal to the folk } \\
\text { lending financing }\end{array}$ & $\begin{array}{l}\text { Slightly larger than the folk lending } \\
\text { financing }\end{array}$ & $\begin{array}{l}\text { Greater than the folk lending } \\
\text { financing }\end{array}$ \\
\hline & Liquidity ratio $\mathrm{A}_{2}$ & $\leq 1$ & $1 \sim 2$ & $\geq 2$ \\
\hline & Risk factor $\mathrm{A}_{3}$ & $\leq 1$ & $1 \sim 2$ & $\geq 2$ \\
\hline & Cash flow debt ratio $\mathrm{A}_{4}$ & $\leq 0.3$ & $0.3 \sim 0.5$ & $\geq 0.5$ \\
\hline & Enterprise credit value degree $A_{5}$ & Low & In general & High \\
\hline \multirow{3}{*}{$\begin{array}{l}\text { Decision risk } \\
\text { indicators B }\end{array}$} & Professional standards $B_{2}$ & Not professional counterparts & Major is related & Professional counterparts \\
\hline & Management experience $\mathrm{B}_{3}$ & Deficient & Average & Plentiful \\
\hline & Risk attitude $\mathrm{B}_{4}$ & Adventurous type & Steady type & Conservative type \\
\hline $\begin{array}{l}\text { Operational risk } \\
\text { indicators C }\end{array}$ & Contract risk $\mathrm{C}_{1} \star$ & No contract & Have a contract but not specification & Contract and specification \\
\hline \multirow{3}{*}{$\begin{array}{l}\text { Legal risk } \\
\text { indicators D }\end{array}$} & High interest rate risk $D_{1} \star$ & $\begin{array}{l}\text { Similar bank lending rate four } \\
\text { times or more }\end{array}$ & $\begin{array}{l}2 \text { times the benchmark lending rate } \\
\text { and above }\end{array}$ & $\begin{array}{l}\text { Below } 2 \text { times the benchmark } \\
\text { lending rate and above }\end{array}$ \\
\hline & Main risk $\mathrm{D}_{2}$ & Borrow from other firms & To underground Banks lending & To the private lending \\
\hline & Use risk $\mathrm{D}_{3}$ & Illegal purposes & $\begin{array}{l}\text { Abnormal production and operation of } \\
\text { other lawful purposes }\end{array}$ & $\begin{array}{l}\text { Normal production and } \\
\text { management purposes }\end{array}$ \\
\hline
\end{tabular}

Note: the table above to add an asterisk for important indicator, if the indicators suggest enterprise financing risk is big, to directly upgrade to enterprise's risk rating, other indicators as secondary indexes. 